\title{
EFL Learners' Problems in Using Tenses: An Insight for Grammar Teaching
}

\author{
RinaListia,rina_listia@ulm.ac.id, ULM, South Kalimantan, Indonesia \\ Emma RosanaFebriyanti, emma.rosana@ulm.ac.id, ULM, South Kalimantan, Indonesia
}

\begin{abstract}
For most Indonesian learners, having a good knowledge of grammar is believed necessary to support their ability in both speaking and writing. One of the grammar parts, namely tenses, is considered challenging to acquire. This study aimed at finding out the learners' problems batch 2018 in using English tenses.By using a multiple-choice test and a questionnaire. The study employed a quantitative approach and described the result in narrative form. The subject of this study was the whole population of English Language Education Program batch 2018, in a total of 98 students. The findings reveal that most of them have problems with past perfect tense $(61 \%)$, past perfect continuous tense $(61 \%)$, and future perfect continuous tense $(67 \%)$. These problems are related to the difficulty in applying the aspect and tense in the right context, first language interference, lack of practice repetition, and students' confidence in using the language. It suggested that language teachers should focus their language instruction not only to form but also to function and meaning of the tenses. Additionally, using various techniques suited to teaching tenses is advisable to increase students' to improve communicative skills.
\end{abstract}

Keywords: grammar, English tenses, problems, EFL learners

\section{INTRODUCTION}

Despite the arguments whether grammar should be ignored or presented in a foreign language teaching, the role of grammar is vital as one component to master the language, particularly for Indonesian learners. Debata and Elturki mention that grammar is one of the most challenging aspects of a foreign language to master, this component of language cannot be neglected or disregarded in language teaching(Debata, 2013; Elturki, 2014). Cakir and Abdulmalik say, "Grammar is the backbone of any language," which means that if one does not know the grammatical rules of a language, he will not be able to communicate well in the language(Abdulmalik, n.d.; Çakır, 2011). The sentences produced by the person might not be understandable, ambiguous, or even meaningless due to incorrect grammatical patterns the person used. Additionally, if the person does not know how those words should arrange to make proper sentences, the communication will not take place. That is why grammar is also called as a "sentence-making machine" by Thornbury (Thornbury, 2006). Considering the significance of morphology in learning a new language, one needs to know the rules of the language as well as how those rules applied in the real context of communication. Due to the main aim of learning grammar in a pedagogical sense is to support learners to be skillful in listening, speaking, reading, and writing.

Grammar can embed in the teaching of other skills or, on the contrary, can deliver in isolation. The needs for having grammar instructions are not only necessary for foreign language and second language learners but also first language ones(Jufrizal, 2014). Debata argues that anyone who tries to communicate by using a particular language, whether it is consciously or not, becomes aware of the grammar of that language(Debata, 2013). It means that all language teachers need to pay attention to the appropriate methods and materials of

86 | IJET $\mid$ Volume. 9, Issue 1. July 2020 Copyright 2020 RinaListia \& Emma RosanaFebriyanti are licensed under Creative Commons AtrributionShareAlike 4.0 International License. 
grammar learning since the primary purpose of having grammar instruction in foreign language learning is to have sufficient grammatical competence to support communicative competence in the language. However, from years of learning grammar, Indonesian students still suffer difficulty when they asked to speak or write in English. There is no guarantee that if the students get a good mark in grammar, they would be able to make correct, fluent, and organize sentences. Concerning this, Azarmentions that her Generation 1.5 students have poor grammar ability(Azar, 2007). Students who cannot understand how sentence structures also cannot see how one sentence relates to another or how the sentences in a paragraph relate. Consequently, those who have problems in writing also experience the same difficulty with their academic reading.

In Priyanto and Amin L. study, they found students of SMAN 1 Sidoarjo's grammar competence moderately correlates with their speaking fluency(Priyanto, 2013). Nonetheless, there were also findings that several students who scored high in the grammar test yet performed poorly in a speaking test. In contrast, some students achieved speaking fluency, but their grammar competence is no special. As they argue, it might be because the teaching activities did traditionally; that is, the teacher explains the materials and asks the students to do some exercises related to the explanation. As Çakırmentions, the teacher generally focuses the teaching on teaching the rules and forgets the communicative aspects of the language(Çakır, 2011). The impact of this way of teaching is proven to have benefits, and numerous students are decently good at resolving grammatical problems or similar issues which involve inactive English. Still, they failed when they asked to perform their ability in speaking (Priyanto, 2013).

To master the grammar of the language, in this case, English, the learners need to know what should learn in grammar. There is an assumption that English is a difficult language with lots of complex grammatical rules to master and mastering grammar is a complicated process that requires the users be able to decide about when and why to use one form in speaking or writing rather than the other; this kind of decision requires grammatical proficiency (Elturki, 2014). One of the grammar parts is so-called tenses. It widely knows that tenses are an essential part that needs to be mastered by EFL learners. Since grammar is related to the construction of correct sentences, the learners must be able to express the sentences in the right form of tenses. Which correct tense that the learners should use in the sentence, shows their proficiency in the language. However, English and Indonesian language have different typologies on grammatical features and constructions(Jufrizal, 2014). Typologically, English belongs to tenseness languages; meanwhile, the Indonesian language is tenseless. Based on this, most learners in Indonesia are having difficulties in understanding and using English tenses and aspects appropriately. Moreover, Parrott says that "some learners find choosing between the tenses difficult because their language does not make this kind of distinction"(Parrot, 2010). Additionally, since English tenses related to the change of verbs which does not exist in the Indonesian language, Cowanargues, "use of verb forms is one of the two or three most difficult areas for English language learners to master"(Cowen, 2008).

Based on the explanation above, mastering English tenses and being able to decide which of those tenses must use in communication is vital to students of the English Language Education Study Program as EFL learners. Some of those students are going to be English teachers one day, and they are going to teach tenses to their learners. If they show about tenses wrongly due to their inadequate knowledge, it would be very inconsiderate that their students will also suffer the same problem in tenses. As a result, they undergo many difficulties while they are trying to communicate by using correct English sentences both in spoken in written forms. Since learning a new language is a bit different, the students may experience some slips, errors, false beginnings, and several ungrammatical or ambiguous sentences. Therefore, teachers should be able to identify the most common grammar problems and try to adapt their teaching since employing the correct grammar helps the learners to create "clear, well- 
structured, unambiguous sentences"(Elturki, 2014). Accordingly, this study needs to finish to find out what would be the most grammar problems encountered by EFL learners batch 2018 of FKIP LambungMangkurat University in using tenses. Another goal is to give insights for other EFL learners as well as other practitioners or teachers about some applications that might help to overcome the issues.

\section{METHOD}

This research used a quantitative approach and descriptive method. The data took from the test in the form of scores, which then analyzed quantitatively to find out which tense(s) they found the most difficult. Meanwhile, a descriptive analysis method included having detailed descriptions of students' problems using English tenses from the questionnaire.

For this study, batch 2018 took as the population, and there are 98 students in total. They were all chosen for the reasons that they are accessible, quantifiable, and also related to the purpose of the study: they have taken the Basic Grammar course and Intermediate Grammar course at the English Language Education Study Program of LambungMangkurat University. In those two courses, the students learn about 12 English tenses, which becomes the topic of this study. Another reason, if this study has finished and completed, the result will become a reference or information for the teachers or lecturers who teach the next level of grammar course, Advanced Grammar, to make some modifications or changes for the topics of the course. Additionally, the result will also help the teachers of Basic Grammar and Intermediate Grammar courses to make some additional practices or exercises about tenses in their teaching and learning activity. Therefore, the population taken is appropriate and suitable for the study.

The multiple-choice test used was a technique in collecting data. The students are required to fill in the blanks with the correct form of verb tense provided in the brackets. The test consists of 50 items divided into two parts. In part 1, the students must complete short dialogues (number $1-30$ ), and in part II, the students required to complete the paragraphs (number 31 - 50). Meanwhile, a questionnaire had to get more in-depth information about the problems they have in using tenses, as well as their perception of the level of difficulty of the tenses, and the reason why those problems occurred the questionnaire was in the open-ended form questionnaire. The students asked to give a tick $(\sqrt{ })$ on each number of the tense to identify the level of difficulty based on the Likert scale 1 to 5 degree. The level of difficulty is made based on which construction or pattern from each tense they found difficult to remember and which tense is challenging to apply in a context. Next, the students also asked to give the reasons for their choice.

The test and questionnaire begin with the general questions and move to more detailneeded items to get high face validity. For the content validity, the instruments along with descriptions of the intended sample given to one or more judges or validators. Then, look at the definition, read over the items or questions in the instruments, and place a checkmark in front of each item that they feel does not measure the aspects of the definition or other criteria (Fraenkel et al., 1993). Meanwhile, for the test items, since it is an internal-consistency procedure, it requires only a single administration of one form of a test. Thus, to measure the reliability, the researcher implemented the test once to other subjects who have similar characteristics as the intended subjects. The result reliability coefficient shown by Cronbach's Alpha in the SPSS application is .854. Thus, the test has high reliability.

\section{RESULT}

The result of the test revealed that the students have some problems in using some tenses. From the average frequency in the form of a percentage on the table below, future perfect continuous becomes the most challenging tense that the students have (68\%), followed by past

88 | IJET $\mid$ Volume. 9, Issue 1. July 2020 Copyright 2020 RinaListia \& Emma RosanaFebriyanti are licensed under Creative Commons AtrributionShareAlike 4.0 International License. 
complete $(62.2 \%)$ and past perfect continuous tense (62.25\%). Meanwhile, simple present tense and simple future tense are the two most straightforward tenses the students have.

Table 1. Average Problems for Each Tense

\begin{tabular}{|l|c|}
\hline \multicolumn{1}{|c|}{ Tenses } & $\begin{array}{c}\text { Average Frequency } \\
(\mathbf{\%})\end{array}$ \\
\hline simple present tense & 28.2 \\
\hline present continuous tense & 37.5 \\
\hline present perfect tense & 33.8 \\
\hline present perfect continuous tense & 51.4 \\
\hline simple past tense & 39 \\
\hline past continuous tense & 54.5 \\
\hline past perfect tense & 62.2 \\
\hline past perfect continuous tense & 62.25 \\
\hline simple future tense & 30.6 \\
\hline future continuous tense & 51.05 \\
\hline future perfect tense & 58.65 \\
\hline future perfect continuous tense & 68 \\
\hline
\end{tabular}

Following the research procedures to gain data needed in line with the purpose of the study, the questionnaire was as the second instrument. The students asked to provide their perception of the difficulty level in learning 12 English tenses on the Likert scale $1-5$. The level of difficulty based on two things, namely which of the tenses formula that they can easily remember and which of the tense they find the most difficult to apply in a context. After that, they asked to give reasons for the options they choose.

Table 2. Difficulty Level of Tenses based on the Tenses Formula

\begin{tabular}{|c|l|c|c|c|c|c|}
\hline No & \multicolumn{1}{|c|}{ English Tenses } & $\begin{array}{c}\text { very } \\
\text { easy (1) }\end{array}$ & $\begin{array}{c}\text { easy } \\
(2)\end{array}$ & $\begin{array}{c}\text { average } \\
(3)\end{array}$ & $\begin{array}{c}\text { difficult } \\
(4)\end{array}$ & $\begin{array}{c}\text { very } \\
\text { difficult (5) }\end{array}$ \\
\hline 1. & simple present tense & 61.2 & 16.3 & 12.2 & 8.2 & 2.0 \\
\hline 2. & present continuous tense & 50.0 & 20.4 & 22.4 & 6.1 & 1.0 \\
\hline 3. & present perfect tense & 20.4 & 15.3 & 40.8 & 16.3 & 7.1 \\
\hline 4. & $\begin{array}{l}\text { present perfect continuous } \\
\text { tense }\end{array}$ & 8.2 & 12.2 & 14.3 & 20.4 & 44.9 \\
\hline 5. & simple past tense & 10.2 & 25.5 & 32.7 & 27.6 & 4.1 \\
\hline 6. & past continuous tense & 9.2 & 19.4 & 27.6 & 38.8 & 5.1 \\
\hline 7. & past perfect tense & 8.2 & 10.2 & 16.3 & 19.4 & 45.9 \\
\hline 8. & $\begin{array}{l}\text { past perfect continuous } \\
\text { tense }\end{array}$ & 5.1 & 6.1 & 10.2 & 28.6 & 50.0 \\
\hline 9. & simple future tense & 15.3 & 20.4 & 29.6 & 18.4 & 16.3 \\
\hline 10. & future continuous tense & 10.2 & 12.2 & 19.4 & 35.7 & 22.4 \\
\hline 11. & future perfect tense & 8.2 & 10.2 & 12.2 & 41.8 & 27.6 \\
\hline 12. & $\begin{array}{l}\text { future perfect continuous } \\
\text { tense }\end{array}$ & 5.1 & 5.1 & 10.2 & 35.7 & 43.9 \\
\hline
\end{tabular}

From the table above, it appeared that the most straightforward tenses to remember the formula chosen by the students were simple present tense and present continuous tense. On the

89 | IJET $\mid$ Volume. 9, Issue 1. July 2020

Copyright 2020 RinaListia \& Emma RosanaFebriyanti are licensed under Creative Commons Atrribution- 
contrary, the most difficult tenses to remember were past perfect continuous tense, past perfect tense, and future perfect continuous tense. This level of difficulty is in line with the result of students' test on those three tenses in which they gained worse results.

From the reason, the students replied that the formulas of the three tenses are quite challenging to remember, especially if there is "perfect" included in the name of the tenses. Furthermore, the students sometimes got confused and interchangeably the formula because they said that they all looked alike. The students also stated that they could not recognize and recall what tense should use if there is no time signal in a sentence. Besides the formulas, the students found that it was difficult as well to select the appropriate verb forms related to the tenses that are whether they should apply verb 1 , verb 2 , or verb 3 , or whether the verb is regular or irregular one.

Table 3. Difficulty Level of Tenses based on The Context Application

\begin{tabular}{|c|l|c|c|c|c|c|}
\hline No & \multicolumn{1}{|c|}{ English Tenses } & $\begin{array}{c}\text { very } \\
\text { easy (1) }\end{array}$ & $\begin{array}{c}\text { easy } \\
(2)\end{array}$ & $\begin{array}{c}\text { average } \\
(3)\end{array}$ & $\begin{array}{c}\text { difficult } \\
(4)\end{array}$ & $\begin{array}{c}\text { very } \\
\text { difficult (5) }\end{array}$ \\
\hline 1. & simple present tense & 49.0 & 27.6 & 12.2 & 8.2 & 4.1 \\
\hline 2. & present continuous tense & 39.8 & 23.5 & 22.4 & 6.1 & 6.1 \\
\hline 3. & present perfect tense & 20.4 & 15.3 & 40.8 & 16.3 & 7.1 \\
\hline 4. & $\begin{array}{l}\text { present perfect continuous } \\
\text { tense }\end{array}$ & 6.1 & 10.2 & 14.3 & 20.4 & 46.9 \\
\hline 5. & simple past tense & 12.2 & 26.5 & 32.7 & 27.6 & 4.1 \\
\hline 6. & past continuous tense & 7.1 & 14.3 & 27.6 & 38.8 & 29.6 \\
\hline 7. & past perfect tense & 6.1 & 9.2 & 16.3 & 19.4 & 49.0 \\
\hline 8. & $\begin{array}{l}\text { past perfect continuous } \\
\text { tense }\end{array}$ & 5.1 & 6.1 & 10.2 & 28.6 & 51.0 \\
\hline 9. & simple future tense & 15.3 & 20.4 & 29.6 & 18.4 & 13.3 \\
\hline 10. & future continuous tense & 10.2 & 12.2 & 19.4 & 35.7 & 20.4 \\
\hline 11. & future perfect tense & 8.2 & 10.2 & 12.2 & 41.8 & 31.6 \\
\hline 12. & $\begin{array}{l}\text { future perfect continuous } \\
\text { tense }\end{array}$ & 5.1 & 5.1 & 7.1 & 35.7 & 46.9 \\
\hline
\end{tabular}

Meanwhile, for the students' perception of how the tenses used in a context, the students were also selected past perfect continuous tense, past perfect tense, and future perfect continuous tense as the most challenging tenses to use in a real context. Still, the easiest ones were simple present tense and present continuous tense.

For this reason, it shows that the students have problems when it comes to the tenses that they rarely use, such as past perfect continuous tense and future perfect continuous tense. They do not understand how to use them and in what context they apply. The majority of the students answered that those tricky tenses are hard to understand than other basic tenses. Moreover, they responded that those three tenses are not too important since they rarely are used in a conversation and not existed in the Indonesian language. The signals "Sudah," "Akan," and "Sedang" in future perfect continuous are problematic in application since they are against each other in meaning. Additionally, although they remember all constructions of the tenses, they encountered problems on how to apply them in proper situations.

As aforementioned, the majority of the students have problems with past perfect tense, past perfect continuous tense, and future perfect continuous tense. This finding indicates that the students are in difficulties in understanding and to use complex tenses. The three tenses have the "perfect" aspect, and it creates problems for either elementary or advanced levels of EFL learners (Richards, 2005). The result of this research is more or less the same with 
(Alzuhairy, 2016; Fallay, 1998; Garrido\& Rosado Romero, 2012; Jufrizal, 2014)in which future continuous tense, future perfect continuous tense, and past perfect continuous tense are the top three the most difficult tenses and rarely used by the learners in their writing; meanwhile, present continuous tense, simple present tense, past simple, and present perfect tenses as the easiest ones and have the most occurrences in EFL learners oral and writing productions.

The problems that foreign language learners have, especially the English Language Education Study Program batch 2018 is related to what had previously mentioned, "different typologies on grammatical features and constructions of English and Indonesian languages" (Jufrizal, 2014). Indonesian learners are having difficulties in understanding and using English tenses and aspects appropriately. Therefore, choosing what tense should use in a sentence as well as the changing verbs in the tense is difficult for the learners since their language does not mark this kind of distinction (Cowen, 2008; Parrot, 2010).

The past perfect tense is frequently associated with past tense since past perfect used to say that something happened before another event in the past. It is to show what had begun earlier before another event before now. Likewise, past perfect continuous tense is also combined with past tense to show when the action was happening over time before something began in the past. This thing makes the students confused since both tenses have only a little bit difference or sometimes no difference in meaning, especially if the verbs like a living, work, and stay put in sentences. For example, Maria had lived in this city before she moved to Jakarta; and Maria had been living in this city before she moved to Jakarta. Both sentences are correct and complete; however, the students have misconceptions and misinterpretations to recognize the true meaning and function of those tenses.

Meanwhile, with the future perfect continuous, the students are unsuccessful to differentiate future, perfect, and continuous in one frame since they felt chaotic with the pattern and the verb applied in this tense. For instance, in the sentence When Maria gets home, we will have been eating dinner for about 10 minutes, the students must use will to show the future, have to show that it is perfect, and been eating to indicate the continuous. Linguistically, the Jufrizalstate's tense and aspect are dissimilar to one another(Jufrizal, 2014). The terms past, present, and future called tenses, while continuous (progressive) and perfect belong to aspect. Hofmann (1993) in (Jufrizal, 2014), Cowen, Rahman, and Ali define tense that is related to time, and time refers to 'when' an action or an event takes place; before now, right now, after now, or even all the time(Cowen, 2008; Rahman \& Ali, 2015). Meanwhile, aspect expresses how speakers see the event or view the action of the verb, whether it is continuing (bounded), completed (perfect), iterative (repeated), intermittent (imperfect), regularly (chronic), or other possibilities.

The tense in English may stand alone or may combine with other tenses(s) and with another aspect(s). For example, past perfect tense is a merge between the past as a tense, and perfect as an aspect. Meanwhile, past perfect continuous tense and future perfect continuous tense are constructions between past and future as tenses, and perfect and continuous as aspects. Those various combinations of tense and aspects create serious problems for the learners since they are grammatically complex, full of semantic properties, and full of theoretical explanations. In a tenseless language like the Indonesian language, the concept of tense and aspect do not even exist or are not very important. On the contrary, in English, this concept is unavoidable. However, they are all just called tenses for academic and practical purposes (Jufrizal, 2014).

If we are discussing tense and aspect, we must inevitably argue about the form of the verb included in the tense. Cowen (2008) states that the use of verb forms is one of the most difficult areas for English language learners to master. This case also happens to the learners in the English Language Education Study Program batch 2018. They make mistakes in the proper use of verb forms to suit the tense and aspect to express the time of an event in the target 
language. It means time is needed to determine the form of the verb. In the tense, the verb not only must be concord or related to time. It also can be showed and formed in a different form (present, past, future) by changing the verb form. Tense is formed either by changing the verb (e.g., make, made, enjoy, enjoyed) or by adding auxiliary verbs (e.g., will make; have enjoyed). Accordingly, the Indonesian language does not have any changes in the verb form to show different uses of tense. Another example, the Indonesian language has only one way to indicate future time, that is, the use of adverb of time like "besok" or tomorrow; however, English has multiple tenses and ways to indicate the future tense (Larsen-Freeman, 2000). Cowenstates that the three 'dimensions' or the forms of the verbs play a significant role in denoting the meaning of the sentence, and as has been mentioned before, they also present difficulties of learning English(Cowen, 2008).

Rahman and Ali also have the same experience in their study of Bengali learners of English who have completed their secondary education(Rahman \& Ali, 2015). They failed to understand the form of past tense using an auxiliary and the past participle form of the verbs instead of using the past form of the verbs. Therefore, it is an indication that the learners have problems in using verbs to indicate past time, and they sometimes do not use any auxiliary to indicate whether the action is in the present or the past. Such problems observed in these sentences. I finished the work instead of I did the work, and I was going with my father instead of I am/was going with my father. The learners produced the last sentence may due to the L1 interference of the Bengali language since progressive action does not require any extra auxiliary. Besides, the Bengali learners also failed to understand the concept of aspect in their English made sentences. They made a sentence like I am reading every day in the evening instead of I read every day in the evening. The time marker everyday specifies that the action is constant, hence simple in aspect; however, the Bengali learners view it as temporal and progressive in aspect.

These examples have proven that EFL learners are having difficulties in understanding and applying the tense and aspect of the English language since sometimes, a certain tense points a specific time but express different aspect. They are also indications that they cannot remember the patterns and apparent with the presentation of the various forms of the verbs to specify the specific tense. As in Wahyuningtyas and Bram's study, the learners have admitted that they can easily forget the constructions of each tense and faced difficulty in applying the formula in the correct context(Wahyuningtyas\& Bram, 2018). Larsen-Freeman, Kuehn, \&Haccius and Alzuhairygive clarification that each verb tense may serve to some different functions or usages, and it creates a problem as well for EFL learners, especially(Alzuhairy, 2016; Larsen-Freeman, 2000). They mention simple present tense as an example which has eight different functions, namely habitual actions or events in the present I sleep every night, general facts The earth is round, a statement She is beautiful, speech acts Ineed you in my team, the narration of a story A beautiful girl lives in the wood and stays there happily, future events The trains leaves at 7.10, and the conditional clause If you love me, you will do everything for $m e$. These different functions lead to confusion for the students of English Language Education Study Program batch 2018 as have been revealed by the result of the questionnaire in this study.

Another reason that clarifies the difficulty of EFL learners has is that English has its structure. Cakirand Sunarto(2012) in Wahyuningtyas\& Bram mention that when the learners learn English, they keep comparing English to their first language(Çakır, 2011; Wahyuningtyas\& Bram, 2018). It said as the interference of the systems of the first language. The learners should consider the differences or if there might be similarities between English and Indonesian by doing contrastive analysis. This hypothesis claims that structures that are similar to the learners' first language will be easier to learn than those who are different. Even though there are some other sources of errors that make L2 and FL students difficult to acquire English besides interference, this part of the discussion focuses only on interference since the

92 | IJET $\mid$ Volume. 9, Issue 1. July 2020 Copyright 2020 RinaListia \& Emma RosanaFebriyanti are licensed under Creative Commons AtrributionShareAlike 4.0 International License. 
students make it.

The interference of the first language in students' production in learning English at any level of education is not a new thing. Some studies have been dealing with this phenomenon, such as Cakirwho mention that Turkish students still confronted with English due to their mother tongue interference(Çakır, 2011). When the learners find unfamiliar structures in their foreign language learning, they compare it with the familiar structure from their L1. As an example, the students misuse the present continuous as they confuse it with the simple present tense. Then he proposes remedial teaching and choices of materials to teach forms to help the students learn the tenses better. Another work from Handayani and Johan found there were many parts where the fourth-semester students of PuteraBatam Universityproduced grammatical errors in their written production(Handayani\& Johan, 2018). When the participants asked to write a paragraph without any preparations, they lost their monitoring system and control in the grammatical accuracy. Those findings might occur in language learners' productions in their process of acquiring a new language or second language where the errors mostly influenced by their mother tongue/ L1. From the error categories, it can be said that those errors are affected by the Indonesian grammar which all the participants had already acquired since they started to learn their first language.

The overcome these problems, Collins suggests that the focus of teaching and learning should be more on context-manipulation exercises(Collins, 2007). In these exercises, the students had asked to supply or manipulate contexts in given forms to suit the contexts that they have already known. Moreover, within EFL contexts, materials should also focus on the differences between the L1 and the TL. Learners need to be made aware of the areas where they may make errors due to their L1 interference. Grammar books need to focus on the lexical aspect rather than sticking merely to the traditional pedagogy of tense through the grammatical rules. In the meantime, Azarrecommends that other varieties in grammar materials or teachermade exercises not only should focus on form but also on meaning, and particular attention should be given to the development of speaking, listening, writing, and reading skills (Azar, 2007). Besides, she advocates the teachers need to take into consideration the course purposes and the best use of available teaching time. They need to consider the students' learning preferences, educational and grammar backgrounds, skill level, and academic or work goals, among other things. The high frequency of errors on some tenses is an indication that the learners have problems with the correct use of aspects of the tenses (Garrido\& Rosado Romero, 2012). They suggest implementing the learners' remedial tasks to raise awareness of the importance of the aspect and more exercises on contrasting some tenses which have the most similar aspect and uses. Besides, Jufrizalrecommends five strategies to put English tenses and aspects into pedagogical grammar, namely the explanation and description have to be simpler and practical, the simple and complex tenses should be taught orderly based on the level of complexities and difficulties, the learning materials should be comprehensive and interesting, the teaching should be in serious attention through the explanation in the form of combination between descriptive and prescriptive points of view, especially at intermediate and advanced levels, and finally, to allow either teachers or learners to grasp and to build communicative competence by using learners' first language, translation, and/or through code-switching (Jufrizal, 2014).

In conclusion, many Indonesia learners of EFL, especially students of the English Language Education Study Program, batch 2018 feel that learning and understanding English grammar are problematic and confusing, especially the English tenses and aspects. As a result, the students of the English Language Education Study Program batch 2018 have some problems. These happen due to some factors such as difficulty in applying the tense and aspect in the right context and situation, difficulty in recognizing the change of verb forms to relate the time and tense, difficulty in recognizing the difference between English and Indonesian

93 | IJET $\mid$ Volume. 9, Issue 1. July 2020 Copyright 2020 RinaListia \& Emma RosanaFebriyanti are licensed under Creative Commons AtrributionShareAlike 4.0 International License. 
language structures, and the interference of students' first language in learning English structure. Therefore, learning grammar, especially understanding tenses, is highly indispensable to achieve grammatical-communicative competence. Grammar is one of the components of a language besides pronunciation, spelling, and vocabulary. Though tense and aspect are difficult and complicated, the teaching and learning of tense should help the students to build language awareness and to increase communicative skills.

\section{CONCLUSION}

This study attempts to find out the problems of the students in the English Language Education Study Program batch 2018 in using 12 English tenses. Based on data analysis from the test and questionnaire distributed to the students, it can be concluded that among the 12 English tenses, past perfect tense, past perfect continuous tenses, and the students assume future perfect continuous tense as the most challenging tenses. They found it hard to memorize the intricate patterns or the formulas as well as to apply them in a situation since they seldom use these tenses. Next, the problems that mostly contribute to students' difficulties are differences between English and Indonesian language in the form of tense and aspect, and the interference of the students' first language.

It expected that students who learn English either as a second language or a foreign language still make grammatical errors, especially in tenses, as this is part of learning. However, as a teacher, we must know how to help them to avoid the same errors to happen in the future and to make suitable suggestions and solutions. Therefore, this study suggests some advice and solutions that finish in the future. First, the teachers should focus the teaching and learning of grammar on the tenses in which their students are usually confused, such as past perfect tense, past perfect continuous tenses, and future perfect continuous tense. This step can be done by focusing on the contexts in which the tenses usually used, and by varying the materials and exercises that integrate all skills to make the students more familiar with the tenses forms and applications. Next, the material writers should pay attention to the importance of some verb tenses over others and shows the significant differences between the twelve verb tenses. Since textbooks play an essential role in the teaching and learning process of grammar, the materials and activities should bring into practice and build to suit in any context the students may encounter. Third, the students should do more training intensely, especially that they find the most difficult. They should have more effort in doing exercises in all tenses in various forms and usages by applying them both in oral and written ways.

The current study has shown that EFL learners encountered problems for some tenses which have a long formula and rarely used. Due to some limitations, the findings of this study may not be generalizable. Therefore, it is suggested for future researchers to investigate further whether similar problems happen in their context of education as well to yield more generalizable findings. Then, it is also advisable to find out whether there is any correlation between students' ability to use tenses with their proficiency in all skills of English. Finally, other core grammar topics such as passive voice, conditionals, articles, or prepositions are worth discussing to find out more about grammar difficulties among EFL learners by utilizing other instruments for more reliable results. 


\section{REFERENCES}

Abdulmalik, A. A. A. (n.d.). The Difficulties of Learning the English Tenses in Marib's Schools: Issues and Needs. Aligarh: International Journal of Pure and Applied Management Sicences, 3(1).

Alzuhairy, U. (2016). The frequency of the twelve verb tenses in academic papers written by native speakers. University of Central Florida: Electronic Theses and Dissertations, 2004-2019. 5282. https://stars.library.ucf.edu/etd/5282.Azar, B. (2007). GrammarBased Teaching: A Practitioner's Perspective. Tesl-Ej, 11(2), n2.

Çakır, İ. (2011). Problems in teaching tenses to Turkish learners. Finland: Theory and Practice in Language Studies, 1(2), 123-127.

Collins, L. (2007). L1 differences and L2 similarities: Teaching verb tenses in English. Tulane University: ELT Journal, 61(4), 295-303.

Cowen, R. (2008). The Teacher's Grammar of English: A Course Book and Reference Guide. New York: Cambridge University Press.

Debata, P. K. (2013). The importance of grammar in the English language teaching-A reassessment. India: Language in India, 13(5), 482-486.

Elturki, E. (2014). An investigation of grammar problems facing English language learners. United States: Humanizing Language Teaching, 16(2).

Fallay, I. (1998). English tenses and aspects: Are they too difficult for Arab students to master. Jazan University, Saudi Arabia: Advances in Language and Literary Studies.

Fraenkel, J. R., Wallen, N. E., \& Hyun, H. H. (1993). How to design and evaluate research in education (Vol. 7). McGraw-Hill New York.

Garrido, C. G., \& Rosado Romero, C. (2012). Errors in the use of English tenses. Íkala, Revista de Lenguaje y Cultura, 17(3), 285-296.

Handayani, N. D., \& Johan, M. (2018). Problem faced in the grammar of EFL students. KhazanahIlmuBerazam, 1(2 SEPT), 33-41.

Jufrizal, J. (2014). Tense and Aspect of English In Pedagogical Grammar: How essential are they for EFL Learners in Indonesia. Indonesia: Proceedings of ISELT FBS Universitas Negeri Padang, 2, 265-274.

Larsen-Freeman, D. (2000). Techniques and principles in language teaching. Great Clarendon Street: Oxford University.

Parrot, M. (2010). Grammar for English language teachers. Great Clarendon Street: Cambridge University Press.

Priyanto, A. (2013). The correlation between English grammar competence and speaking fluency of eleventh-grade students in Sman 1 Sidoarjo. Sidoarjo: RETAIN, 1(1).

Rahman, M. S., \& Ali, M. (2015). Problems in mastering English tense and aspect and the role of the practitioners. IOSR Journal of Humanities and Social Science, 20(1), 131-135.

Richards, J. C. (2005). Communicative language teaching today. SEAMEO Regional Language Centre Singapore. New York: Cambridge University Press.

Thornbury, S. (2006). How to teach vocabulary. India: Pearson Education.

Wahyuningtyas, E. W., \& Bram, B. (2018). Basic Tense Problems Of The First Semester Students Of English Language Education Study Program. International Journal of Indonesian Education and Teaching (IJIET),2(2), 147-153. 